\title{
Radioactive elements in atmospheric precipitations of the Western Siberia
}

\author{
Mikhail Melgunov ${ }^{1,2, *}$, Kseniya Mezina ${ }^{1}$, Boris Sherbov ${ }^{1}$, Yuliya Vosel $^{1}$, Inna Zhurkova ${ }^{1}$, \\ and Dmitriy Belyanin ${ }^{1,2}$ \\ ${ }^{1}$ V.S. Sobolev Institute of Geology and Mineralogy, Siberian Branch of Russian Academy of \\ Sciences, Koptyug Ave., 3, Novosibirsk, 630090, Russia \\ ${ }^{2}$ Novosibirsk State University, 630090, Novosibirsk, Pirogova st., 1, Russia
}

\begin{abstract}
The radionuclide composition of the atmospheric precipitations (rain and snow) fell out on the territory of the South of the Western Siberia in 2016-2017 was studied. It is shown that, the maximum of deposition of ${ }^{7} \mathrm{Be}$ and ${ }^{210} \mathrm{~Pb}$ were observed in a foothill zone $\left(618\right.$ and $\left.171 \mathrm{~Bq} / \mathrm{m}^{2}\right)$, the minimum - in the Alpine zone (104 and $\left.27 \mathrm{~Bq} / \mathrm{m}^{2}\right)$, for the forest-steppe zone these values are $237-340 \mathrm{~Bq} / \mathrm{m}^{2}$ and $73-93 \mathrm{~Bq} / \mathrm{m}^{2}$. Deposition density of ${ }^{137} \mathrm{Cs}$ in comparison with ${ }^{210} \mathrm{~Pb}$ and ${ }^{7} \mathrm{Be}$ is small and does not exceed 1 $\mathrm{Bq} / \mathrm{m}^{2}$. Average values of total specific activities of ${ }^{210} \mathrm{~Pb}$ and ${ }^{7} \mathrm{Be}$ in rain waters are 242 and $2434 \mathrm{mBq} / \mathrm{l}$, in the snowmelt -506 and $1611 \mathrm{mBq} / \mathrm{l}$. ${ }^{7} \mathrm{Be} /{ }^{210} \mathrm{~Pb}$ activity ratio in rain waters more than three times higher, than in snowmelt: 10,1 to 3,2 . The highest values of ${ }^{7} \mathrm{Be} /{ }^{210} \mathrm{~Pb}$ activity ratios are observed in the finest fraction $(<0.45 \mu \mathrm{m})$ of the suspended matter: 19 - in rain and 10 - in snowmelt waters.
\end{abstract}

\section{Introduction}

Radioactive isotopes of natural origin ${ }^{7} \mathrm{Be}$ and ${ }^{210} \mathrm{~Pb}$ in significant amounts deposit on the Earth's surface from the atmosphere. They have different sources of origin. ${ }^{7} \mathrm{Be}$, with a half-life of 53.2 days, is a cosmogenic radionuclide naturally produced in the stratosphere and troposphere through cosmic-ray spallation of nitrogen and oxygen $[1,2] .{ }^{210} \mathrm{~Pb}_{\text {atm }}$ is a decay product of atmospheric gaseous ${ }^{222} \mathrm{Rn}$ derived from soil ${ }^{238} \mathrm{U}$ decay chain and emanated to the atmosphere from the Earth's surface. Just after production ${ }^{7} \mathrm{Be},{ }^{222} \mathrm{Rn}$ atoms and its decay products are electrically charged. They attach to aerosols and dust particles and deposit on the Earth's surface with "dry" (dust, aerosols) fallouts and "wet" (rain, snow) atmospheric precipitations [3-11]. ${ }^{7} \mathrm{Be}$ and ${ }^{210} \mathrm{~Pb}_{\text {atm }}$ are often used as indicators of various natural processes, including, geochronological modeling of modern sedimentation processes, study of aerosol transfer in the atmosphere, atmospheric circulation models and meteorological dynamics, etc. [12-29] According to some estimates [30] more than $90 \%$ of ${ }^{7} \mathrm{Be}$ and ${ }^{210} \mathrm{~Pb}_{\mathrm{atm}}$ are delivered to the Earth's surface through "wet" atmosphere precipitations. There are no reliable data about deposition of ${ }^{210} \mathrm{~Pb}$ and ${ }^{7} \mathrm{Be}$ with atmospheric precipitations in such extensive region as the Western Siberia now. The

*Corresponding author: mike@igm.nsc.ru 
purpose of this research is to estimate concentration levels and to reveal the main features of ${ }^{7} \mathrm{Be}$ and ${ }^{210} \mathrm{~Pb}$ deposition with the atmospheric precipitations (rain, snow) falling out on the territory of some regions of the Western Siberia (South-East of Novosibirsk region, South-East of Altai Territory, North-West of Altai Republic).

\section{Materials and methods}

In this research samples of the wet atmospheric precipitations (rain, snow) fell out in 2016 and 2017 on the territory of the South of the Western Siberia in different landscapegeographical zones (Fig. 1, forest-steppe (I, II, III), foothill (IV), mountain-taiga (V) and Alpine (VI)) were studied. The volume of samples of snowmelt or rainwaters was 10-20 liters. During the sample preparation procedure of the studied water samples the separation of the suspended matter was performed by sequential filtering of all sample volume via the $3,0 \mu \mathrm{m}$ filter and the $0,45 \mu \mathrm{m}$ membrane. It allowed to allocate two components of the suspended matter with dimensions more than $3 \mu \mathrm{m}$ and $3-0,45 \mu \mathrm{m}$ corresponding to dust particles of various sizes. The water solution received after filtering was evaporated to solid residual. This fraction $(<0,45 \mu \mathrm{m})$ include fine aerosol and dust particles, colloids and dissolved component. In filters and solid residual determination of activities of ${ }^{7} \mathrm{Be},{ }^{210} \mathrm{~Pb}$ and ${ }^{137} \mathrm{Cs}$ was carried out on ORTEC gamma-spectrometer with HPGe well-type detector. All analytical procedures were performed at the Shared-Use Center for Multielemental and Isotope Studies, Siberian Branch of the Russian Academy of Sciences.

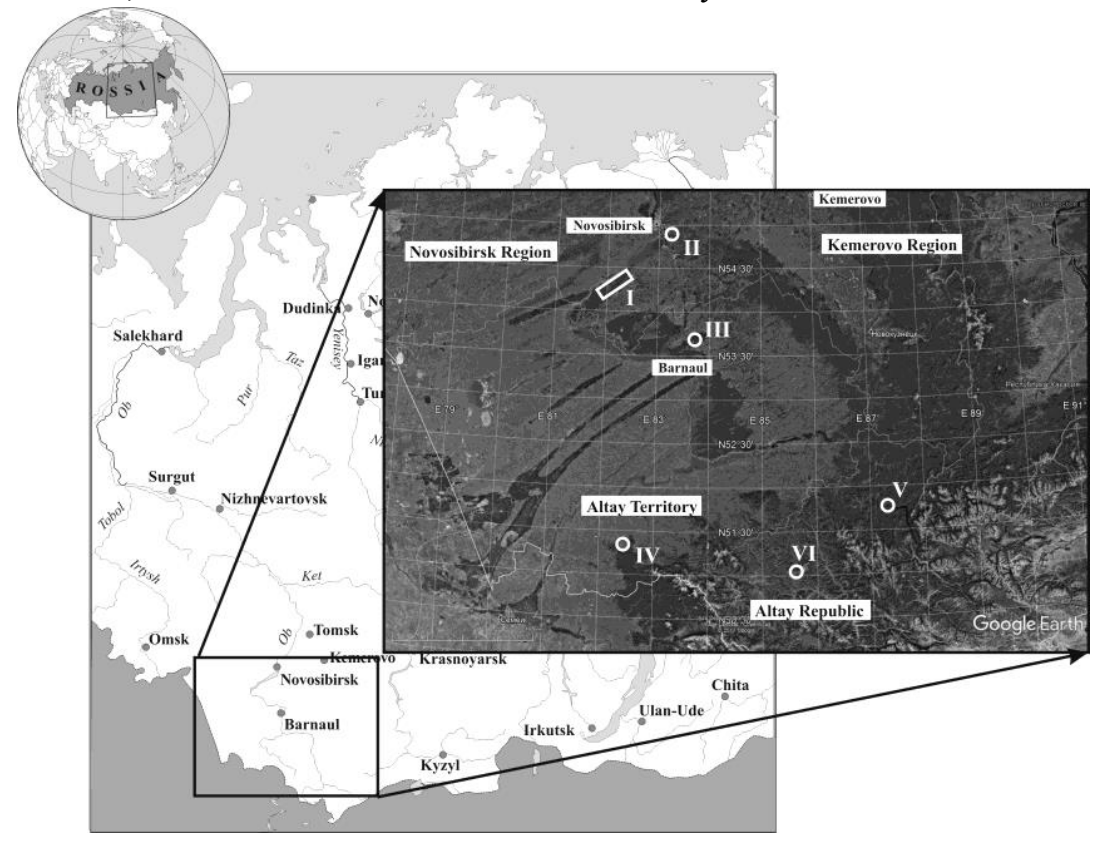

Fig. 1. Study area and sampling locations.

\section{Results and discussions}

The study of the samples of the snow precipitations accumulated over the entire winter season and collected at the end of the period of an active snow accumulation (the end of March) in various landscape-geographical zones of the South of the Western Siberia showed that (Fig. 2.): 
a) Deposition density of ${ }^{137} \mathrm{Cs}$ in comparison with ${ }^{210} \mathrm{~Pb}$ and ${ }^{7} \mathrm{Be}$ is small and does not exceed $1 \mathrm{~Bq} / \mathrm{m}^{2}$ in all studied points. This fact indicates the insignificant modern content of this radionuclide in the atmosphere.

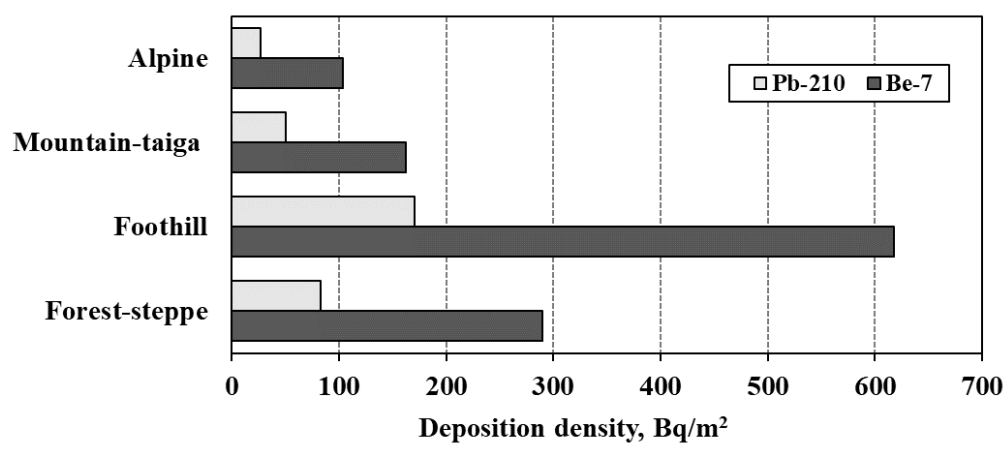

Fig. 2. Average values of the deposition densities of $\mathrm{Be}-7$ and $\mathrm{Pb}-210$ within various landscapegeographical zones of the South of the Western Siberia.

b) The maximum of deposition densities of ${ }^{7} \mathrm{Be}$ and ${ }^{210} \mathrm{~Pb}$ were observed in a foothill zone $-618 \pm 62$ and $171 \pm 17 \mathrm{~Bq} / \mathrm{m}^{2}$, respectively. The minimum values corresponded to the Alpine zone $-104 \pm 11$ and $27 \pm 4 \mathrm{~Bq} / \mathrm{m}^{2}$. For the forest-steppe zone deposition densities of ${ }^{7} \mathrm{Be}$ and ${ }^{210} \mathrm{~Pb}$ varied within $237-340 \mathrm{~Bq} / \mathrm{m}^{2}$ and $73-93 \mathrm{~Bq} / \mathrm{m}^{2}$, respectively.

The comparative analysis of radionuclide composition of "wet" atmospheric precipitations (10 rain and 8 snow samples) on the territory of the South of the Western Siberia shows:

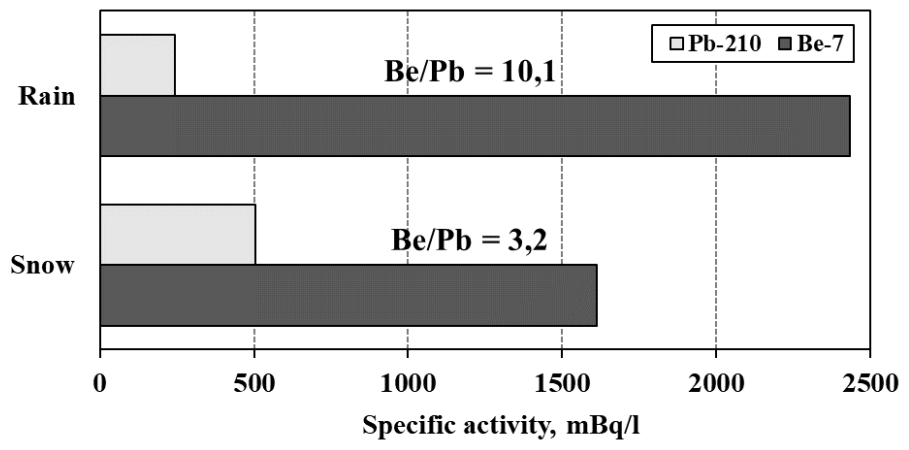

Fig. 3. Average integrated specific activities of $\mathrm{Pb}-210$ and $\mathrm{Be}-7$ in rain and snowmelt waters.

a) Taking into account a contribution of all granulometric fractions of the suspended matter, average values of total specific activities of ${ }^{210} \mathrm{~Pb}$ and ${ }^{7} \mathrm{Be}$ in rain waters, sampled in the spring and autumn period of 2017, are $242 \pm 23$ and $2434 \pm 200 \mathrm{mBq} / 1$, respectively (see Fig. 3). In the snowmelt waters characterizing single snowfalls of the winter period of 2017 , these values are $506 \pm 45$ and $1611 \pm 130 \mathrm{mBq} / \mathrm{l}$. It is obvious that concentration of ${ }^{210} \mathrm{~Pb}$ in winter "wet" precipitations is almost twice higher, than in summer one. The specific activity of ${ }^{7} \mathrm{Be}$ is much higher during the summer period. This fact can be explained by more active ingress of this isotope from an upper atmosphere during the spring and summer period. It should be noted that ${ }^{7} \mathrm{Be} /{ }^{210} \mathrm{~Pb}$ activity ratio in rain waters more than three times higher, than in snowmelt: 10,1 to 3,2 .

b) The study of ${ }^{210} \mathrm{~Pb}$ and ${ }^{7} \mathrm{Be}$ distribution in granulometric fractions of the suspended matter of rain and snowmelt waters showed that (Fig. 4) in fraction with dimension more than 3 microns activities of ${ }^{210} \mathrm{~Pb}$ and ${ }^{7} \mathrm{Be}$ in rain waters are $191 \pm 19 \mathrm{mBq} / 1$ and $1859 \pm 150$ 
$\mathrm{mBq} / \mathrm{l}$, in snowmelt waters $-403 \pm 35$ and $1206 \pm 110 \mathrm{mBq} / 1$, respectively; 2 ) in fraction 0,45 3 microns these values are equal $26 \pm 3,119 \pm 12 \mathrm{mBq} / 1$ and $85 \pm 9,226 \pm 22 \mathrm{mBq} / \mathrm{l}$, and in fraction $<0,45$ microns $-24 \pm 3,456 \pm 37$ and $18 \pm 2,180 \pm 18 \mathrm{mBq} / 1$. These results show that the highest values of ${ }^{7} \mathrm{Be} /{ }^{210} \mathrm{~Pb}$ activity ratios are observed in the finest fraction of the suspended matter: 19 - in rain and 10 - in snowmelt waters. This fraction consists of fine aerosol and dust particles, colloids and dissolved components. Moreover, it is the concentrator of ${ }^{7} \mathrm{Be}$. In spite of the fact that in more coarse-grained fractions the total amount of ${ }^{210} \mathrm{~Pb}$, and ${ }^{7} \mathrm{Be}$ is much higher, ${ }^{7} \mathrm{Be} /{ }^{210} \mathrm{~Pb}$ activity ratios here are significantly less: 4,5-10 in rain and about 3 in snowmelt waters. As these fractions are generally presented by the dust particles of various dimension, it is possible to assume that the concentrator of ${ }^{210} \mathrm{~Pb}$ are these particles.

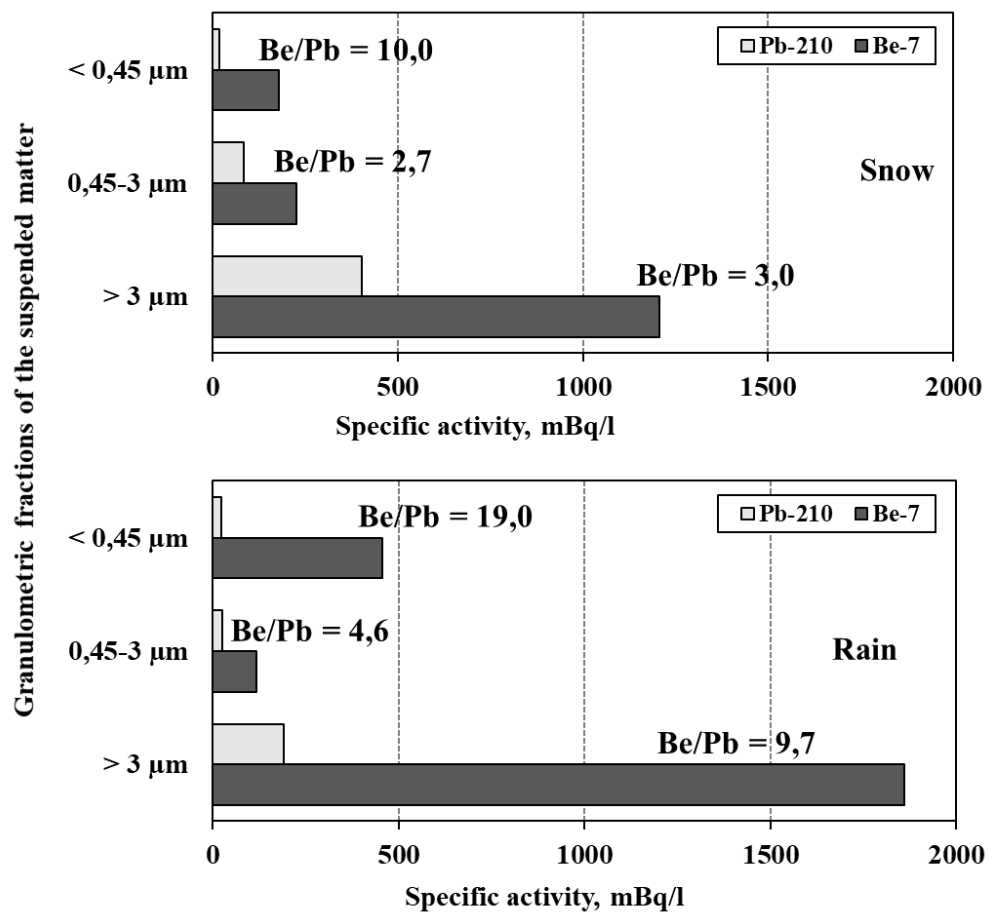

Fig. 4. Average specific activities of $\mathrm{Pb}-210$ and $\mathrm{Be}-7$ in granulometric fractions of the suspended matter of rain and snowmelt waters.

Acknowledgements. Field trip, preliminary sample preparation and ${ }^{7}$ Be determination were carried out as a part of a governmental contract (Project 0330-2016-0011) with additional support by grant 17-05-41076 RGO_a from the Russian Foundation for Basic Research. Additional geochemical analyses including perfection of ${ }^{210} \mathrm{~Pb}$ and ${ }^{137} \mathrm{Cs}$ analytical data and final theoretical generalization of the results were carried out under support of project 18-77-10039 from the Russian Science Foundation.

\section{References}

1. D. Lal, P.K. Malhotra, B.Peters, J. Atmos. Terr. Phys. 12 (4), 306-328 (1958)

2. C. Papastefanou, A. Ioannidou, J. Environ. Radioact. 26, 273-282 (1995)

3. C.R. Olsen, I.L. Larsen, P.D. Lowry, N.H. Cutshall, J.F. Todd, G.T.F. Wong, W.H. Casey, J. Geophys. Res. Atmos. 90, 10487-10495 (1985) 
4. A.S. Murray, J.M. Olley, P.J. Wallbrink, Rad. Prot. Dosim. 7, 297-304 (1992)

5. P.J. Wallbrink, A.S. Murray, J. Environ. Radioact. 25, 213-228 (1994)

6. S. Caillet, P. Arpagaus, F. Monna, J. Dominik. J. Environ, Radioact. 53, 241-256 (2001)

7. D. McNeary, M. Baskaran, J. Geophys. Res., 4210 (2003)

8. S.R. Daish, A.A. Dale, C.J. Dale, R. May, J.E. Rowe, J. Environ. Radioact. 84, 457467 (2005)

9. A. Ioannidou, C. Papastefanou. J. Environ. Radioact. 85, 121-136 (2006)

10. C.H. Conaway, C.D. Storlazzi, A.E. Draut, P.W. Swarzenski, J. Environ. Radioact. 120, 94-103 (2013)

11. L. Jiwen, V.N. Starovoitova, D.O. Wells, J. Environ. Radioact. 116, $42-47$ (2013)

12. S. Rehfeld, M. Heimann. J. Geophys, Res. Atmos. 100, 26141-26161 (1995)

13. D.M. Koch, D.J. Jacob, W.C. Graustein. J. Geophys, Res. Atmos. 101, 18651-18666 (1996)

14. C. Papastefanou, A. Ioannidou, Aerosol Sci Tech 24, 102-106 (1996)

15. D. Koch, D. Rind. J. Geophys, Res. Atmos. 103, 3907-3917 (1998)

16. M. Baskaran, G. E. Shaw. J. Aerosol, Sci. 32, 443-452 (2001)

17. M. Krmar, K. Wattanavatee, D. Radnovic, J. Slivka, T. Bhongsuwan, M.V. Frontasyeva, S.S. Pavlov. J. Environ. Radioact, 117, 45-48 (2013)

18. C. M. Alonso-Hernandez, Ya. Morera-Gomez, H. Cartas-Aguila, A. GuillenArruebarrena, J. Environ. Radioact. 138, 149-155 (2014)

19. B.R.R. Persson, E. Holm. J. Environ, Radioact. 138, 364-374 (2014)

20. J. Du, M. Baskaran, Q. Bi, D. Huang, Y. Jiang. J. Geophys, Res. Atmos. 120, 43234339 (2015)

21. M. A. Hernández-Ceballos, G. Cinelli, M.M Ferrer, T. Tollefsen, L. De Felice, E. Nweke, P.V. Tognoli, S. Vanzo, M. De Cort, J. Environ. Radioact. 141, 62-70 (2015)

22. E. Gordo, E. Liger, C. Duenas, M.C. Fernandez, S. Canete, M. Perez. J. Environ, Radioact. 148, 141-153 (2015)

23. S.N. Wilkinson, J.M. Olley, T. Furuichi, J. Burton, A.E. Kinsey-Henderson. J. Soils, Sediments. 15, 2038-2051 (2015)

24. A. Aba, A. M. Al-Dousari, A. Ismaeel, J. Radioanal. Nucl. Ch. 307, 15-23 (2016)

25. M. Krmar, D.T. Mihailović, I. Arsenić, D. Radnović, I. Pap, Sci. Total. Envion. 541, 941-948 (2016)

26. J. D. Landis, C. E. Renshaw, J. M. Kaste, Geochim. Cosmochim. Ac. 180, 109-125 (2016)

27. A. Taylor, M.J. Keith-Roach, A.R. Iurian, L. Mabit, W.H. Blake. J. Environ, Radioact. 160, 80-86 (2016)

28. Y.Y. Yoon, D.C.Koh, K.Y.Lee, S.Y.Cho, J. Radioanal. Nucl. Ch. 307, 1629-1633 (2016)

29. I. Sýkora, K. Holý, M. Jeskovský, M. Müllerova, M. Bulko, P.P. Povinec. J. Environ, Radioact. 166, 27-35 (2017)

30. M. Baskaran. J. Geophys, Res. Atmos. 100, 2833-2840 (1995) 